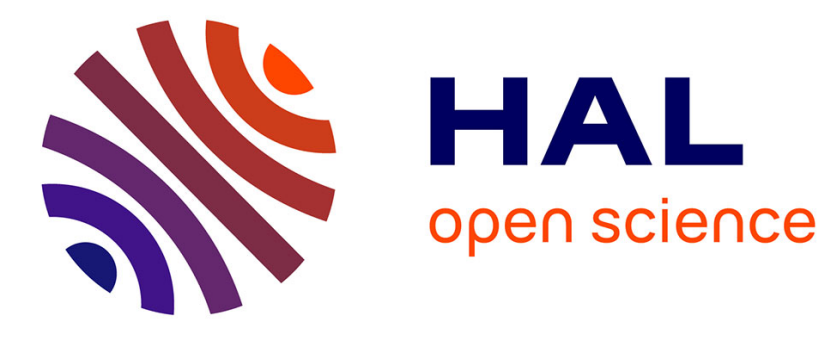

\title{
Site recognition and substrate screens for PKN family proteins
}

\author{
Alejandra Collazos, Nicholas Michael, Richard Dh Whelan, Gavin Kelly, \\ Harry Mellor, Leon C. H. Pang, Nick Totty, Peter J Parker
}

\section{To cite this version:}

Alejandra Collazos, Nicholas Michael, Richard Dh Whelan, Gavin Kelly, Harry Mellor, et al.. Site recognition and substrate screens for PKN family proteins. Biochemical Journal, 2011, 438 (3), pp.535543. 10.1042/BJ20110521 . hal-00617330

\section{HAL Id: hal-00617330 \\ https://hal.science/hal-00617330}

Submitted on 27 Aug 2011

HAL is a multi-disciplinary open access archive for the deposit and dissemination of scientific research documents, whether they are published or not. The documents may come from teaching and research institutions in France or abroad, or from public or private research centers.
L'archive ouverte pluridisciplinaire HAL, est destinée au dépôt et à la diffusion de documents scientifiques de niveau recherche, publiés ou non, émanant des établissements d'enseignement et de recherche français ou étrangers, des laboratoires publics ou privés. 


\title{
Site recognition and substrate screens for PKN family proteins.
}

\author{
Alejandra Collazos*, Nicholas Michael†, Richard, D. H. Whelan*, Gavin Kellył, Harry \\ Mellor§, Leon C. H. PangII, Nick Totty† and Peter J. Parker , ${ }^{* *}$,
}

\begin{abstract}
*Protein Phosphorylation Laboratory, London Research Institute, Cancer Research UK, 44 Lincoln's Inn Fields, London WC2A 3PX, UK

†Protein Analysis Laboratory, London Research Institute, Cancer Research UK, 44 Lincoln's Inn Fields, London WC2A 3PX, UK ‡Bioinformatics and Biostatistics Service, London Research Institute, Cancer Research UK, 44 Lincoln's Inn Fields, London WC2A 3PX, UK

$\S D e p a r t m e n t$ of Biochemistry, School of Medical Sciences, University of Bristol, Bristol, UK TCancer Research Technology Ltd, Wolfson Institute for Biomedical Research, The Cruciform Building, Gower Street, London, WC1E 6BT, UK ** Division of Cancer Studies KCL, New Hunt's House, Guy's Campus, London SE1 1UL, UK

${ }^{1}$ To whom correspondence should be addressed (email peter.parker@eancer.org.uk)
\end{abstract}

Corresponding author: Peter J. Parker, Protein Phosphorylation Laboratory, London Research Institute, Cancer Research UK, 44 Lincoln's Inn Fields, London WC2A 3PX, UK Tel: +44-(0)207-269-3513; Fax: +44-(0)207-269-3094; peter.parker@cancer.org.uk

\section{Synopsis}

The protein kinase $\mathrm{C}$ related kinases (PRKs also referred to as PKNs) are a kinase family important in diverse functions including migration and cytokinesis. Here, we have reevaluated and compared specificity for PKN1 and PKN3, and assessed predictive value in substrates. We analysed the phosphorylation consensus motif of PKNs using a peptide library approach and demonstrate that both PKN1 and 3 phosphorylate serine residues in sequence contexts that have an arginine at position -3. In contrast, PKN1 and 3 do not tolerate Arg in position +1 and -1 respectively. To test the predictive value of this motif, site analysis was performed on the PKN substrate CLIP170; a PKN target site was identified that conformed to the predicted pattern. Using a protein array, we identified 22 further substrates for PKN1, of which 20 were previously undescribed substrates. To evaluate further the recognition signature, the site on one of these hits, EGFR, was identified. This identified threonine 654 in EGFR as the PKN1 phosphorylation site and this retains an arginine at the -3 position. Finally, the constitutive phosphorylation of EGFR on Thr-654 is shown to be modulated by PKN in vivo.

Short title: PKN sites and substrates

Keywords: Protein Kinase N; substrates; phosphorylation consensus motif.

Abbreviations used: AA, arachidonic acid; $\mathrm{PKC}$, protein kinase $\mathrm{C}, \mathrm{PKN}$, protein kinase $\mathrm{N}$, EGFR epithelial growth factor receptor; PI3K, phosphoinositide3-kinase. 


\section{INTRODUCTION}

The PKC-related kinase family are a subfamily of the serine/threonine kinases with a Cterminal kinase domain closely related to those of $\mathrm{PKC}$ while their amino termini are distinct comprising a conserved repeated domain $(\mathrm{HR} 1 \mathrm{a}, \mathrm{b}, \mathrm{c})$ followed by a C2-related domain. PKNs are activated by fatty acids [1] and phospholipids in vitro [2], although the in vivo significance of this activation remains unclear [3].

The PKN family play an important role in diverse functions including regulation of cell cycle [4], receptor traffic [5], vesicle transport [6] and apoptosis [7]. The PKNs are implicated in signal transduction as effectors of Rho, Rac and PI3Kinase [8-10]. In particular, PKN1 has been linked to stress-induced pathways implicated upstream of c-Jun transcription via p38 activation induced on hyperosmotic stress [11] with associated activation of PKN1 [6]. PKN is also linked to the ligand-dependent transcriptional activation of the androgen receptor [12, 13]. PKN1 has been implicated as well in milk secretion by regulating the tight junction in the mammary gland [14]. PKN2 plays a role alongside fyn in controlling cell-cell adhesion in keratinocytes [15] and the maturation of apical juctions [16]. PKN2 can modulate as well migration in astrocytes by up-regulating cortactin phosphorylation [8]. PKN3 has been identified as an effector required for malignant cell growth downstream of activated PI3K [9]. More recently, it has been shown that knock-down of PKN3 can decrease the growth of prostate and pancreatic tumours and prevents lung metastasis in mouse models $[17,18]$.

More than 20 proteins and several peptides have been shown to be phosphorylated by PKN1 and PKN2 including $\alpha$-actinin, adducin, Cdc25C, vimentin and TRAF1 [1, 2, 13, 19-30]. In contrast, there are no known substrates for PKN3. The phosphorylation consensus motif of a protein helps to determine which substrates are phosphorylated by a kinase. Concerning PKN phosphorylation consensus motifs, Zhu et al. had evaluated the importance of Arg in $7 \mathrm{~N}$ terminal and $3 \mathrm{C}$-terminal positions of serine directed peptides for several kinases, including PKN1. [31]. Very recently, Shiga et al confirmed these results using a combinatorial peptide library method. [32]. These observations provide a theoretical prediction for PKN phosphorylation motifs.

The developing of new technologies such as peptide and protein arrays has made it practical to investigate the optimal phosphorylation consensus motif and identify new substrates and partners, not only for one kinase, but for several proteins at the same time [31, 33, 34]. Here we have investigated kinase substrate specificity of PKN1 and PKN3 re-evaluated using a peptide array and assessed utility using newly reported substrates for the kinase. We confirm that PKN1 follows the phosphorylation consensus motif by the phosphorylation in vitro of a newly identified PKN substrate, CLIP-170. Furthermore, novel substrates for PKN1 were identified using a protein array. These results were validated by identifying the site of EGFR phosphorylation by PKN1 as Thr-654; this site conforms to the consensus defined by peptide array and is shown to be modulated in vivo through PKN.

\section{EXPERIMENTAL}

\section{Reagents}

Arachidonic acid was purchased from Sigma. Total EGFR (1005) sc-03 Antibody was purchased from Santa Cruz Biotechnology, Inc. EGFR Thr-654 [3F2] Antibody was purchased from Abcam (antibody 78283). PKN1 antibody (BD 610687) was purchased from BD biosciences, PKN2 antibody (Cat 2612) was from Cell Signalling and PKN3 antibody (NBP1-30102) from Novus biologicals. Tubulin $\alpha$ clone B-5-1-2 antibody was from Sigma. EGFR L861Q protein (Cat number PV3873) was purchased from Invitrogen. $\left[\gamma-{ }^{32} \mathrm{P}\right]-\mathrm{ATP}$ 
was purchased from PerkinElmer. $\left[\gamma_{-}{ }^{33} \mathrm{P}\right]$-ATP was purchased from GE Healthcare. EGF was from Calbiochem. The peptide arrays (Pepchip kinomics) were bought from Pepscan Presto BV, Lelystad, The Netherlands. The protoarrays were from Invitrogen. CLIP-170 was a kind gift from Frank Perez [35].

\section{DNA cloning and Protein production}

The full length cDNAs for human PKN1 and PKN3 were subcloned into a modified pFastbac-1 vector (Invitrogen) that encodes an N-terminal glutathione S-transferase (GST) tag and a thrombin cleavage site. Recombinant baculoviruses were generated using the Bacto-Bac Baculovirus Expression System (Invitrogen). Routine baculovirus production of human GST-PKN1 and GST-PKN3 in Spodoptera frugiperda cells (Sf9 cells) was achieved. The first 650 amino acids of CLIP-170 or the whole protein was fused to GST into the pGEX-2TK vector. To subclone the first 650 amino acids and the whole CLIP-170, one common forward primer was used: 5'ggatccatgagtatgctaaagccaagtggg3, A reverse primer 5'gaattctcacctcaaggcttccatctcttt3' was used to subclone the first 650 amino acids and the primer 5'gaattctcagaaggtttcgtcgtcattgca3' was used to subclone the whole protein. The recombinant proteins were produced and purified from E. coli. The GST fused to CLIP-170 was removed by incubating the purified protein with thrombin at $4^{\circ} \mathrm{C}$ overnight.

\section{Peptide Array}

A peptide array (Pepchip kinomics) with specific phosphorylation sites was used to study PKNs phosphorylation consensus motif. Each array has 960 peptides of 11 amino acids long derived from known phosphorylation sites from human protein sequences. In addition, each peptide comes annotated with reported upstream kinases. Moreover, the peptides that belong to a substrate have a physiological relevance in stress, growth, differentiation and other responses. The glass slides contain 976 peptides (including 16 control peptides) spotted in triplicate.

For array kinase assays, the glass slides containing the peptides were incubated with each PKN in the following buffer: $20 \mathrm{mM}$ Tris $\mathrm{pH} .7 .5,40 \mu \mathrm{M}$ Arachidonic acid, $4 \mathrm{mM} \mathrm{MgCl}$, $10 \%$ Glycerol, $0.01 \mathrm{mg} / \mathrm{ml} \mathrm{BSA,} \mathrm{0.01 \%} \mathrm{V/V} \mathrm{Brij-35,} 10 \mu \mathrm{M}$ ATP and $300 \mu \mathrm{Ci} / \mathrm{ml}\left[\gamma_{-}{ }^{33} \mathrm{P}\right]-$ ATP. PKN1 and PKN3 were diluted to $26 \mu \mathrm{g} / \mathrm{ml}$ and $13 \mu \mathrm{g} / \mathrm{ml}$ respectively in a buffer containing $20 \mathrm{mM}$ Tris $\mathrm{pH} 7.5,1 \mathrm{mM}$ EDTA pH 8, 0.2\% Triton X-100 and $1 \mathrm{mM}$ DTT.

PKN1, PKN3 or no kinase were incubated on the PepChip kinomics arrays for $2 \mathrm{~h}$ in a humidified incubator at $37^{\circ} \mathrm{C}$. Subsequently, the arrays were washed in $2 \mathrm{M} \mathrm{NaCl}, 1 \%$ Triton $\mathrm{X}-100$, PBS, $0.1 \%$ Tween 20 and water, after which slides were dried and exposed to an Xray film screen for $2 \mathrm{~h}$ or $24 \mathrm{~h}$ for PKN1 and 3 respectively, in order to visualise in the linear range the reaction.

Imaging of the incorporated $\left[\gamma-{ }^{33} \mathrm{P}\right]$-ATP was performed using a conventional scanner (Epson Expression 1680). Data analysis was performed using Microsoft Excel and the R Statistical Package (http://www.R-project.org). After image acquisition and quantification using ImageQuantTL software (Amersharm, Biosciences), the data of each triplicate was normalized with a median-centring method. Signals with high intensity in the PKN slide but low intensity in the control (no PKN) slide were considered as peptide substrates recognised by PKN1 or PKN3. After performing an ANOVA F-Test, the peptides that had a p-value higher than $9.7 \times 10^{-4}$ were eliminated. The peptides were sorted by spot intensity and the top 20 peptides based were chosen to analyse the phosphorylation consensus motif of each kinase using the WebLogo v3 application (http://weblogo.threeplusone.com/) [36].

\section{Protein arrays}

Glass slides containing 4700 human proteins from Invitrogen were used to identify PKN1 substrates. The slides were incubated with PKN1 following the manufacturer's instructions 
with the following modifications. Briefly, the slides were incubated with the kinase in $20 \mathrm{mM}$ Tris $\mathrm{pH}$ 7,5, $40 \mu \mathrm{M}$ Arachidonic Acid, $4 \mathrm{mM} \mathrm{MgCl}_{2}, 1 \% \mathrm{NP} 40,5 \mathrm{mg} / \mathrm{ml} \mathrm{BSA}, 1 \mu \mathrm{M}$ ATP, and $33 \mathrm{nM}\left[\gamma_{-}{ }^{33} \mathrm{P}\right]-\mathrm{ATP}$. PKN1-GST was diluted in a buffer containing $20 \mathrm{mM}$ Tris $\mathrm{pH} 7.5$, $1 \mathrm{mM}$ EDTA $\mathrm{pH} 8,0.2 \%$ Triton $\mathrm{X}-100$ and $1 \mathrm{mM}$ DTT (the final concentrations in the protein array assay were: $168 \mu \mathrm{M}$ EDTA, $0.033 \%$ Triton X-100 and $168 \mu \mathrm{M}$ DTT). The final PKN1-GST concentration in the assay was $52 \mathrm{nM}$. The slides were incubated with or without (control) kinase for $1 \mathrm{~h}$ at $37^{\circ} \mathrm{C}$. The slides were exposed to an X-ray film for different times, scanned and the spots were analysed using the software provided by Invitrogen in order to identify the hits.

\section{Kinase Assay}

Three $\mu \mathrm{g}$ of CLIP-170 or $0.3 \mu \mathrm{g}$ of EGFR L861Q (Invitrogen, PV3873) were incubated with PKNs in $20 \mathrm{mM}$ Tris $\mathrm{pH} 7,5,40 \mu \mathrm{M}$ Arachidonic Acid, $4 \mathrm{mM} \mathrm{MgCl}, 100 \mu \mathrm{M}$ ATP, and $0.025 \mu \mathrm{Ci}\left[\gamma_{-}{ }^{32} \mathrm{P}\right]-\mathrm{ATP}$. PKN1 and PK3 were diluted at $310 \mathrm{nM}$ and $50 \mathrm{nM}$ respectively in a buffer containing $20 \mathrm{mM}$ Tris $\mathrm{pH} 7.5,1 \mathrm{mM}$ EDTA $\mathrm{pH} 8,0.2 \%$ Triton $\mathrm{X}-100$ and $5 \mathrm{mM}$ DTT (the final concentrations in the kinase assay were: $166 \mu \mathrm{M}$ EDTA, $0.033 \%$ Triton X100 and $833 \mu \mathrm{M}$ DTT). The kinases were incubated with the substrates for different times at $30^{\circ} \mathrm{C}$. The reactions were stopped by adding Nupage sample buffer $4 \mathrm{x}$ (Invitrogen), resolved by SDS-PAGE, Coomassie stained, dried and exposed to X-ray film.

\section{Western blot}

SDS-PAGE was performed using the NuPAGE system (Invitrogen) with 4-12\% Bis-Tris gels. Proteins were transferred to a PVDF membrane and probed as indicated in the Figure legends. Levels of PKN1, 2 and 3 in A431 were quantified against recombinants PKN1, 2 and 3 by westerns blot. Quantitation was derived using an ImageQuant LAS 4000 mini instrument to obtain a series of exposures of the ECL readout; ImageJ was used to determine the levels of expression relative to recombinant PKN proteins.

\section{Mass spectrometry}

In vitro phosphorylated CLIP-170 was reduced with $10 \mathrm{mM}$ dithiothreitol (Sigma) followed by alkylation with $50 \mathrm{mM}$ iodoacetamide (Sigma) prior to digestion in-gel with trypsin (Promega) overnight at $37^{\circ} \mathrm{C}$. Extracted peptides were analysed by on-line nanoLC-MS/MS using a linear ion trap instrument (Applied Biosystems Q-TRAP 4000).

\section{siRNA Transfection}

A431 cells were maintained in DMEM/10\% FBS (Gibco) + penicillin/streptomycin at $37^{\circ} \mathrm{C}$, in a humified atmosphere containing $10 \% \mathrm{CO}_{2}$. On the first day, the cells were transfected with $25 \mathrm{nM}$ siRNA Luciferase (AATCGAAGTATTCCGCGTACG) or PKNs (8.33 nM each PKNs: PKN1 (AAGGGCACGGGAACTGGAGTT), PKN2 (AAGCATGGCATGTGTCTCTATT) and PKN3 (GAGAGCCTGTACTGCGAGAAG; as described elsewhere [9]). siRNA transfections were carried out with Lullaby (OZBiosciences). $24 \mathrm{~h}$ later, the medium was replaced by fresh medium. $96 \mathrm{~h}$ after the siRNA transfection, the media was replaced by $\mathrm{CO}_{2}$ independent media/0.5\% FBS (Gibco) for 5h. The cells were collected on Nupage LDS sample buffer 2x (Invitrogen) + 2 mM EDTA.

\section{RESULTS}




\section{PKN phosphorylation consensus motif}

We used a peptide library in order to study the influence of the residues up to 5 amino acids away (C-terminal and N-terminal) from candidate phosphorylation sites for PKN1 and PKN3. Based on the top 20 phosphorylated peptides (Fig. 1A), PKN1 and PKN3 were shown to have a preference for the phosphorylation of Serines, which have an Arg in position -3 (Fig. 1B and Fig. S1). In fact PKN1 and 3 show an 80 and $85 \%$ preference for Arg in position -3 , respectively. In contrast, $\mathrm{PKN} 1$ and 3 do not tolerate Arg in position +1 and -1 respectively. PKN1 shows a $50 \%$ and $40 \%$ of preference for Arg in positions +2 and -2 respectively. In addition, PKN3 shows a 70\% preference for hydrophobic amino acids (Ile, Met, Leu, Val, Phe, Trp, Tyr) in position +1 against a $55 \%$ preference for PKN1. These PKNs show a strong preference (at least 70\%) for neutral amino acids (Ser, Gly, His, Thr, Ala, Pro) in position -5 for PKN1 and -1 and +5 for PKN3. Finally, PKN1 shows a $70 \%$ preference of hydrophilic amino acids (Arg, Lys, Asp, Glu, Asn, Glu) in position -2. If we take a $70 \%$ preference cut-off, the PKN1 phosphorylation consensus motif is Ne-X-Arg-Hi-XSer-Z-X-X-X-X and the PKN3 is $\mathrm{x}-\mathrm{x}-\mathrm{Arg}-\mathrm{x}-\mathrm{Ne} / \mathrm{Z}-\mathrm{Ser}-\mathrm{Ho}-\mathrm{x}-\mathrm{x}-\mathrm{x}-\mathrm{Ne}$. (where $\mathrm{x}$ denotes a position with no strict amino acid requirements, $\mathrm{Z}$ a position strictly not tolerating Arg, $\mathrm{Ne}$ a neutral amino acids, Hi a hydrophilic amino acid and Ho a hydrophobic amino acid). Even though, PKN1 and 3 phosphorylated peptides were not identical, the kinases share peptide substrates in the array. Of the 20 top hits for each kinase, 5 peptides were hits for both PKN1 and 3; of the top 30, 12 peptides were hits for PKN1 and 3. The results indicate that PKN1 and $\mathrm{PKN} 3$ share recognition, but retain some specificity.

\section{PKN phosphorylates CLIP-170}

The identification of a PKN phosphorylation consensus motif was assessed using the hitherto uninvestigated PKN substrate CLIP-170 (H. Mellor and P. Parker unpublished data). We confirmed that CLIP-170 is phosphorylated by PKN1 and 3 in vitro. Figure 1C shows that PKN1 phosphorylates equally the N-terminal half of CLIP170 and intact CLIP-170. PKN3 phosphorylates as well the N-terminal half of CLIP-170 as shown in Fig. 1D. By mass spectrometry we identified S312 as a target for PKN, this is a site identified previously as being occupied in CLIP-170 (http://www.phosphosite.org/). Sequence surrounding S312 follows the Arg-X-Ne-S-Z-X-X-X-X-Ne pattern, consistent with the specificity analysis derived from the peptide array (Fig. 1E).

\section{New PKN substrates and partners}

To avoid any bias from the known substrate approach, we performed a protein array in order to identify PKN1 substrates. We found 22 substrates (Fig. 2 and Table 1), of which 20 were previously unidentified (the two known substrates validated the screening approach: CDC25C and Adducin 2 [20, 27]). For the identified substrates, 21 of 22 retain at least one motif that follows the phosphorylation consensus motif Arg-X-X-[Ser/Thr]-X.

\section{PKNs phosphorylate EGFR at a consensus site, Thr-654}

In order to validate the protein array results, we analysed EGFR. To confirm this phosphorylation event, we performed a kinase assay in solution with purified proteins. We compared the sequences of different EGFR constructs spotted on the Invitrogen protein array and we observed 2 different EGFR sequences, only one of which was phosphorylated by PKN1 (Fig. 3A). Sequence analysis of these 2 different versions of EGFR indicates 2 possible sites of phosphorylation that follow the PKN consensus. One site corresponds to Ser 1071. However, the peptide that contains this Ser (Leu-Gln-Arg-Tyr-Ser-Ser-Asp-Pro-ThrGly-Ala) was ranked number 235 in the PKN1 peptide array, so it was unlikely to be the PKN1 phosphorylation site. The second site was Thr-654 and it although it had previously been shown that PKN can phosphorylate in vitro a peptide corresponding to this site (Val- 
Arg-Lys-Arg-Thr-p-Leu-Arg-Arg-Leu) [2, 37] it was unknown if the protein was targeted by PKNs at this site. In order to determine if PKNs could phosphorylate EGFR at Thr-654, we used a site-specific antibody. Figure 3B and Figure S4 shows that Thr-654 is phosphorylated by PKN1 and PKN3 in vitro.

\section{PKNs modulate phosphorylation of EGFR on Thr-654 in cells}

Having demonstrated the phosphorylation by $\mathrm{PKN}$ in vitro, we evaluated if $\mathrm{PKN}$ s contributed to EGFR Thr-654 phosphorylation in vivo. Using siRNAs targeting all three PKN isoforms (all three PKN proteins are expressed in these cells), we observed in A431 cells that the constitutive phosphorylation of Thr-654 in EGFR was decreased in comparison with the control condition (Fig. 3C and 3D). In response to EGF, PKN1/2/3 knock-down did not block the increase in Thr-654 phosphorylation, although there was a reduced total phosphorylation reflective of the basal effect. This indicates that the PKN effect on Thr-654 under basal conditions is independent of EGF and is reflective of a transmodulation pathway.

In order to determine which PKN family member(s) is responsible for this effect, we deconvoluted the PKN siRNAs. PKN1 knock-down was found to have a very similar effect on EGFR Thr 654 phosphorylation as that seen for the knock-down of all PKNs (Fig. 3E,F). PKN2 had a minor effect and PKN3 none at all, although we note that in contrast to PKN1 and PKN2, the knock-down of PKN3 is not efficient in A431 cells. The evidence suggests that the PKN responsible for controlling basal EGFR Thr654 phosphorylation in A431 cells is principally PKN1. This result may reflect the fact that the PKN1 is the major PKN isoform expressed in these cells; quantitative analysis of expression in A431 cells shows that PKN1 is expressed at $0.44 \mu \mathrm{g} / \mathrm{mg}$ of cell protein, PKN2 $0.13 \mu \mathrm{g} / \mathrm{mg}$ of cell protein and PKN3 0.03 $\mu \mathrm{g} / \mathrm{mg}$ of cell protein.

\section{DISCUSSION}

We have analysed the phosphorylation consensus motifs of PKN1 and 3 using a peptide array. PKN1 and 3 selected for similar phosphorylation consensus motifs based on residues both in the $\mathrm{N}$-terminal and $\mathrm{C}$-terminal sides of the phosphorylation site. The phosphorylation consensus motifs are consistent with a previously unmapped site we identify here in the PKN substrate CLIP-170. To further assess the predictive capacity of the motif identified, we used an array approach to identify protein substrates for PKN1. This screen identified a number of in vitro substrates amongst which was the EGFR. The arrayed proteins (two different length forms of EGFR) and the determined sequence specificity of PKN predicted that Thr-654 was targeted by PKN on the EGFR. In vitro we show that EGFR is phosphorylated by PKN1 on Thr-654, consistent with this specificity. Finally, we show that PKN depletion by siRNA decreased the constitutive EGFR phosphorylation on Thr-654 in A431 cells and that this is primarily a function of PKN1. We conclude that PKN specificity has predictive capacity as applied to both a predetermined substrate (CLIP170) and a newly identified protein substrate (EGFR). In the case of the latter, the phosphorylation at Thr-654 has hitherto been ascribed to $\mathrm{PKC}$; the evidence here is that this is more accurately defined as a PKC superfamily target site.

\section{Phosphorylation consensus motif}

Previous groups have studied PKN phosphorylation motifs. Zhu et al. evaluated only the importance of Arg in positions near the phosphorylated serine in peptides phosphorylated by PKN1 and they did not analyse the importance of other amino acids as the study does here. 
Zhu et al. showed that Arg was important in position -3, -2 and +2 and Arg was not allowed in position +1 and +3 [31]. We confirm these findings, except that we did not find a nonallowance of Arg in position +3: PKN1 and 3 have a preference for Arg in position -3 (80 and $85 \%$ respectively, Fig. 1 and Fig. S1) and a preference in position -2 (40 and 30\% respectively). More recently, Shiga et al. using a combinatorial peptide library method, confirmed the results of Zhu et al. and showed that both PKN1 and PKN3 phosphorylate preferentially serines with an Arg in position -3. Shiga et al. also showed that these kinases have a preference for hydrophobic amino acids in position +1 and basic amino acids downstream of the phosphorylation site [32], concluding that the best phosphorylation consensus motif for PKN1 and PKN3 is Lys-Arg-Arg-Lys-Pro-Ser-Phe-Arg-Asn-Pro. Shiga et al. found a preference for lysine in position -5 and -2 . In general, we see a very similar pattern of recognition here (albeit basic residues rather than any lysine specific preferences). However Shiga et al. noted a preference for proline in position -1 , asparagine in position +3 and proline in position +5 ; we did not find these preferences. These differences between the three studies likely reflects the nature of the arrays: Zhu et al. used degenerate peptides where only Arg is changed, Shiga el al. used degenerate peptides were one amino acid is keep constant and our study used a large array of synthetic peptides based on known target sites. The key feature is however consistent between all three studies and that is the very strong preference for Arg at the -3 position.

Since PKN belongs to the AGC family we expected that the PKN phosphorylation consensus motif would follow a pattern similar to that of other AGC family members. If we compare with other kinases that belong to distinct branches of kinases, it is evident that the pattern is very different. For example, CDC2 phosphorylates peptides with the pattern x-Ser-Pro-x-Lys while CK2 targets the consensus [Ser/Thr]-[Asp/Glu]-X-[Asp/Glu] [38, 39]. These motifs are very different from the PKN motif Arg-X-X-[Ser/Thr]-X-X-X. The presence of Arg in position -3 is similar to other AGC family (basophilic) kinases. (PKC: [Lys/Arg]-X-X-[Ser/Thr]-X[Lys/Arg]; PKA: Arg-Arg-X-[Ser/Thr]-Phe) [39]. It is possible that the presence of peptides phosphorylated by members of the AGC family could influence the PKN results, however if we analyse the whole collection of peptides spotted in the slide (960 peptides), only $20 \%$ present Arg in position -3 (Fig. S2). Therefore it is not the case that the preference of Arg in position -3 by PKN1 and 3 only reflects a bias in the array composition since peptides substrates identified were enriched to $\sim 80 \%$ probability of Arg at the -3 site for PKN1.

PKN and PKC are close phylogenetic neighbours. As expected, they share some similarities in the phosphorylation consensus motif (Fig. S3). The preference of Arg in position -3 and the hydrophobic amino acid in position +1 are significant similarities. If we analyse more closely, PKN1 and 3 have a preference for Arg in position -2 (40 and 30\% respectively, Fig. 1 and Fig. S1) and many PKC substrate peptides have Lys or Arg in this position as well. In addition, PKN1 presents a preference for Arg (50\%) in position +2 as do PKC $\alpha$, and $\eta$; PKC $\beta$ and $\gamma$ prefer a Lys residue here. Concerning PKN3, there is a preference for Arg in position $-5(>30 \%)$, as for PKC $\alpha, \gamma, \delta$ and $\eta$. So, there is a substantial overlap in specificity indicative of shared targets in vivo where phosphorylation is triggered under different circumstances by regulatory inputs particular to individual members this family of proteins [40], controlling the same downstream events. Evidence for such properties have come from the use of a dPKN-dPKC chimera to rescue dPKN loss [41, 42].

It was proposed that $\mathrm{PKN}$ has a pseudosubstrate in the ACC1 region, overlapping the Rho binding domain (Fig. S3). This region corresponds to amino acids 39 to 53. The substitution of Ile-46 with a Ser converts a peptide based on this sequence into a potent substrate for PKN, while the authentic Ile counterpart inhibits activity of PKN [43]. However, the deletion 
of this region does not activate PKN [44]. If we compare this region with the phosphorylation consensus motif, it has an Arg for PKN1, and PKN2 and a Lys for PKN3 in position -3. However, there are some discrepancies between the sequences. For example, the PKN1 region has an Arg in position +1 , while the phosphorylation consensus motif does not permit this amino acid in this position. This could explain why this region (amino acid 39 to 53) does not operate as a pseudosubstrate site. However, as for other proteins, the presence of a consensus phosphorylation site in a protein, does not guarantee that the protein is a substrate in vivo and authentic phosphorylation sites do not always conform to the consensus, [45]. Evidently this is the case as well for PKN. Some peptides that have been shown to be phosphorylated by PKN1 do not follow the phosphorylation consensus pattern (Fig. S3).

\section{PKN substrates and EGFR}

We found 22 susbstrates in vitro of which 15 are kinases. This is a high proportion, reflective of their representation in the protein array. However these are not false positives lighting up because they are protein kinases, since the software is designed to eliminate the kinases that autophosphorylate; in order to define a protein as a hit the mean signal of the replicates (in the PKN1 slide) needs to be at least 1.5 times that of the mean signals from the corresponding proteins on the negative control (no kinase). So, we are confident that these kinases are PKN substrates in vitro.

We have shown that PKN1 phosphorylates EGFR on Thr-654 in vitro and in vivo. The Thr654 site is a known phosphorylation site for PKC in vivo [46, 47]. Thr-654 is located on the cytoplasmic side of the plasma membrane nine residues distant from the transmembrane domain. It has been shown that the phosphorylation of EGER at Thr-654 by PKC reduces the Tyrosine kinase activity of the receptor [47], inhibits lysosomal degradation to promote recycling back to the cell surface [48] and positively mediates drug inhibition of prostate tumour growth in vivo [49].

We found that the PKN effect on Thr-654 phosphorylation was only observed under basal conditions and had little influence on the response to EGF. This suggests that the effect of PKN in Thr-654 phosphorylation under basal conditions is EGF-independent. By contrast the EGFR phosphorylation on Thr-654 by PKC can be the product of EGF binding [50]. That indicates that PKC and PKN can control the same substrate however the input that regulates this phosphorylation event is different. EGFR can be transmodulated by other growth factors [51] and it is anticipated that PKN lies on one of these pathways reflected in its requirement for the basal Thr-654 phosphorylation in A431 cells.

In summary, the peptide and protein library approach has provided information about substrate specificity for PKN1 and PKN3 and new substrates for PKN1. In addition, we have defined CLIP-170 and EGFR as substrates for PKN1 and PKN3 and determined the sites involved. The predictive nature of the specificities defined and the protein substrates identified in vitro should serve to help determine the signalling pathways for these kinases.

\section{AUTHOR CONTRIBUTION}

Alejandra Collazos made the Clip-170 constructs and the experiments presented in the figures of the paper. Nicholas Michael and Nick Totty performed the mass spectrometry experiments. Richard, D. H. Whelan helped with the preliminary EGFR experiments. Gavin Kelly analysed the peptide array data. Harry Mellor identified Clip-170 as a PKN susbstrate. Leon C. H. Pang made the PKN1 and PKN3 recombinant baculoviruses constructs. Alejandra 
Collazos and Peter J. Parker planned the experiments, analysed the data and wrote the manuscript.

\section{ACKNOWLEDGEMENTS}

We should also like to acknowledge the support of CRT who provided the protein arrays. A.C. was funded by the FRM (Foundation de la Recherché Medical, France) and CR-UK.

\section{FUNDING}

This work was supported in part by a grant from the European Commission Research [project no. 503467] and by Cancer Research UK and Cancer Research Technology. 


\section{References}

1 Mukai, H., Kitagawa, M., Shibata, H., Takanaga, H., Mori, K., Shimakawa, M., Miyahara, M., Hirao, K. and Ono, Y. (1994) Activation of PKN, a novel 120-kDa protein kinase with leucine zipper-like sequences, by unsaturated fatty acids and by limited proteolysis. Biochem Biophys Res Commun. 204, 348

2 Yu, W., Liu, J., Morrice, N. A. and Wettenhall, R. E. (1997) Isolation and characterization of a structural homologue of human PRK2 from rat liver. Distinguishing substrate and lipid activator specificities. J Biol Chem. 272, 10030

3 Palmer, R. H., Dekker, L. V., Woscholski, R., Le Good, J. A., Gigg, R. and Parker, P. J. (1995) Activation of PRK1 by phosphatidylinositol 4,5-bisphosphate and phosphatidylinositol 3,4,5-trisphosphate. A comparison with protein kinase C isotypes. J Biol Chem. 270, 22412

4 Schmidt, A., Durgan, J., Magalhaes, A. and Hall, A. (2007) Rho GTPases regulate PRK2/PKN2 to control entry into mitosis and exit from cytokinesis. EMBO J. 26, 1624

5 Gampel, A., Parker, P. J. and Mellor, H. (1999) Regulation of epidermal growth factor receptor traffic by the small GTPase rhoB. Curr Biol. 9, 955

6 Torbett, N. E., Casamassima, A. and Parker, P. J. (2003) Hyperosmotic-induced protein kinase N 1 activation in a vesicular compartment is dependent upon Rac1 and 3phosphoinositide-dependent kinase 1. J Biol Chem. 278, 32344

7 Takagi, H., Hsu, C. P., Kajimoto, K., Shao, D., Yang, Y., Maejima, Y., Zhai, P., Yehia, G., Yamada, C., Zablocki, D. and Sadoshima, J. (2010) Activation of PKN mediates survival of cardiac myocytes in the heart during ischemia/reperfusion. Circ Res. 107, 642

8 Bourguignon, L. Y., Gilad, E., Peyrollier, K., Brightman, A. and Swanson, R. A. (2007) Hyaluronan-CD44 interaction stimulates Racl signaling and PKN gamma kinase activation leading to cytoskeleton function and cell migration in astrocytes. $\mathrm{J}$ Neurochem. 101, 1002

9 Leenders, F., Mopert, K., Schmiedeknecht, A., Santel, A., Czauderna, F., Aleku, M., Penschuck, S., Dames, S., Sternberger, M., Rohl, T., Wellmann, A., Arnold, W., Giese, K., Kaufmann, J. and Klippel, A. (2004) PKN3 is required for malignant prostate cell growth downstream of activated PI 3-kinase. EMBO J. 23, 3303

10 Zhu, Y., Stolz, D. B., Guo, F., Ross, M. A., Watkins, S. C., Tan, B. J., Qi, R. Z., Manser, E., Li, Q. T., Bay, B. H., Teo, T. S. and Duan, W. (2004) Signaling via a novel integral plasma membrane pool of a serine/threonine protein kinase PRK1 in mammalian cells. FASEB J. 18, 1722

11 Marinissen, M. J., Chiariello, M. and Gutkind, J. S. (2001) Regulation of gene expression by the small GTPase Rho through the ERK6 (p38 gamma) MAP kinase pathway. Genes Dev. 15, 535

12 Metzger, E., Muller, J. M., Ferrari, S., Buettner, R. and Schule, R. (2003) A novel inducible transactivation domain in the androgen receptor: implications for PRK in prostate cancer. EMBO J. 22, 270

13 Metzger, E., Yin, N., Wissmann, M., Kunowska, N., Fischer, K., Friedrichs, N., Patnaik, D., Higgins, J. M., Potier, N., Scheidtmann, K. H., Buettner, R. and Schule, R. (2008) Phosphorylation of histone $\mathrm{H} 3$ at threonine 11 establishes a novel chromatin mark for transcriptional regulation. Nat Cell Biol. 10, 53

14 Fischer, A., Stuckas, H., Gluth, M., Russell, T. D., Rudolph, M. C., Beeman, N. E., Bachmann, S., Umemura, S., Ohashi, Y., Neville, M. C. and Theuring, F. (2007) Impaired 
tight junction sealing and precocious involution in mammary glands of PKN1 transgenic mice. J Cell Sci. 120, 2272

15 Calautti, E., Grossi, M., Mammucari, C., Aoyama, Y., Pirro, M., Ono, Y., Li, J. and Dotto, G. P. (2002) Fyn tyrosine kinase is a downstream mediator of Rho/PRK2 function in keratinocyte cell-cell adhesion. J Cell Biol. 156, 137

16 Wallace, S. W., Magalhaes, A. and Hall, A. (2011) The Rho target PRK2 regulates apical junction formation in human bronchial epithelial cells. Mol Cell Biol. 31, 81

17 Aleku, M., Schulz, P., Keil, O., Santel, A., Schaeper, U., Dieckhoff, B., Janke, O., Endruschat, J., Durieux, B., Roder, N., Loffler, K., Lange, C., Fechtner, M., Mopert, K., Fisch, G., Dames, S., Arnold, W., Jochims, K., Giese, K., Wiedenmann, B., Scholz, A. and Kaufmann, J. (2008) Atu027, a liposomal small interfering RNA formulation targeting protein kinase N3, inhibits cancer progression. Cancer Res. 68, 9788

18 Santel, A., Aleku, M., Roder, N., Mopert, K., Durieux, B., Janke, O., Keil, O., Endruschat, J., Dames, S., Lange, C., Eisermann, M., Loffler, K., Fechtner, M., Fisch, G., Vank, C., Schaeper, U., Giese, K. and Kaufmann, J. (2010) Atu027 prevents pulmonary metastasis in experimental and spontaneous mouse metastasis models. Clin Cancer Res. 16, 5469

19 Bourguignon, L. Y., Singleton, P. A. and Diedrich, F. (2004) Hyaluronan-CD44 interaction with Rac1-dependent protein kinase N-gamma promotes phospholipase Cgamma1 activation, $\mathrm{Ca}(2+)$ signaling, and cortactin-cytoskeleton function leading to keratinocyte adhesion and differentiation. J Biol Chem. 279, 29654

20 Fukata, Y., Oshiro, N., Kinoshita, N., Kawano, Y., Matsuoka, Y., Bennett, V., Matsuura, Y. and Kaibuchi, K. (1999) Phosphorylation of adducin by Rho-kinase plays a crucial role in cell motility. J Cell Biol. 145, 347

21 Harrison, B. C., Huynh, K., Lundgaard, G. L., Helmke, S. M., Perryman, M. B. and McKinsey, T. A. (2010) Protein kinase C-related kinase targets nuclear localization signals in a subset of class IIa histone deacetylases. FEBS Lett. 584, 1103

22 Kato, T., Jr., Gotoh, Y., Hoffmann, A. and Ono, Y. (2008) Negative regulation of constitutive NF-kappaB and JNK signaling by PKN1-mediated phosphorylation of TRAF1. Genes Cells. 13, 509

23 Kim, S. J., Kim, J. H., Kim, Y. G., Lim, H. S. and Oh, J. W. (2004) Protein kinase Crelated kinase 2 regulates hepatitis $\mathrm{C}$ virus RNA polymerase function by phosphorylation. $\mathrm{J}$ Biol Chem. 279, 50031

24 Kitagawa, M., Mukai, H., Shibata, H. and Ono, Y. (1995) Purification and characterization of a fatty acid-activated protein kinase (PKN) from rat testis. Biochem J. 310 ( Pt 2), 657

25 Lee, S. J., Stapleton, G., Greene, J. H. and Hille, M. B. (2000) Protein kinase Crelated kinase 2 phosphorylates the protein synthesis initiation factor eIF4E in starfish oocytes. Dev Biol. 228, 166

26 Matsuzawa, K., Kosako, H., Inagaki, N., Shibata, H., Mukai, H., Ono, Y., Amano, M., Kaibuchi, K., Matsuura, Y., Azuma, I. and Inagaki, M. (1997) Domain-specific phosphorylation of vimentin and glial fibrillary acidic protein by PKN. Biochem Biophys Res Commun. 234, 621

27 Misaki, K., Mukai, H., Yoshinaga, C., Oishi, K., Isagawa, T., Takahashi, M., Ohsumi, K., Kishimoto, T. and Ono, Y. (2001) PKN delays mitotic timing by inhibition of Cdc25C: possible involvement of PKN in the regulation of cell division. Proc Natl Acad Sci U S A. 98, 125

28 Palmer, R. H., Schonwasser, D. C., Rahman, D., Pappin, D. J., Herget, T. and Parker, P. J. (1996) PRK1 phosphorylates MARCKS at the PKC sites: serine 152, serine 156 and serine 163. FEBS Lett. 378, 281 
29 Takahashi, M., Gotoh, Y., Isagawa, T., Nishimura, T., Goyama, E., Kim, H. S., Mukai, H. and Ono, Y. (2003) Regulation of a mitogen-activated protein kinase kinase kinase, MLTK by PKN. J Biochem. 133, 181

30 Taniguchi, T., Kawamata, T., Mukai, H., Hasegawa, H., Isagawa, T., Yasuda, M., Hashimoto, T., Terashima, A., Nakai, M., Mori, H., Ono, Y. and Tanaka, C. (2001) Phosphorylation of tau is regulated by PKN. J Biol Chem. 276, 10025

31 Zhu, G., Fujii, K., Liu, Y., Codrea, V., Herrero, J. and Shaw, S. (2005) A single pair of acidic residues in the kinase major groove mediates strong substrate preference for P-2 or P-5 arginine in the AGC, CAMK, and STE kinase families. J Biol Chem. 280, 36372

32 Shiga, K., Takayama, K., Futaki, S., Hutti, J. E., Cantley, L. C., Ueki, K., Ono, Y. and Mukai, H. (2010) Development of an intracellularly acting inhibitory peptide selective for PKN. Biochem J. 425, 445

33 Schnack, C., Hengerer, B. and Gillardon, F. (2008) Identification of novel substrates for $\mathrm{Cdk} 5$ and new targets for $\mathrm{Cdk} 5$ inhibitors using high-density protein microarrays. Proteomics. 8, 1980

34 Vlad, F., Turk, B. E., Peynot, P., Leung, J. and Merlot, S. (2008) A versatile strategy to define the phosphorylation preferences of plant protein kinases and screen for putative substrates. Plant J. 55, 104

35 Perez, F., Diamantopoulos, G. S., Stalder, R. and Kreis, T. E. (1999) CLIP-170 highlights growing microtubule ends in vivo. Cell. 96, 517

36 Crooks, G. E., Hon, G., Chandonia, J. M. and Brenner, S. E. (2004) WebLogo: a sequence logo generator. Genome Res. 14, 1188

37 Morrice, N. A., Gabrielli, B., Kemp, B. E. and Wettenhall, R. E. (1994) A cardiolipinactivated protein kinase from rat liver structurally distinct from the protein kinases $\mathrm{C}$. J Biol Chem. 269, 20040

38 Marin, O., Meggio, F., Draetta, G. and Pinna, L. A. (1992) The consensus sequences for cdc2 kinase and for casein kinase-2 are mutually incompatible. A study with peptides derived from the beta-subunit of casein kinase-2. FEBS Lett. 301, 111

39 Ubersax, J. A. and Ferrell, J. E., Jr. (2007) Mechanisms of specificity in protein phosphorylation. Nat Rev Mol Cell Biol. 8, 530

40 Mellor, H. and Parker, P. J. (1998) The extended protein kinase C superfamily. Biochem J. 332 ( Pt 2), 281

41 Betson, M. and Settleman, J. (2007) A rho-binding protein kinase C-like activity is required for the function of protein kinase $\mathrm{N}$ in Drosophila development. Genetics. 176, 2201

42 Lachmann, S., Jevons, A., De Ryker, M., Casamassima, A., Radtke, S., Collazos, A. and Parker, P. J. (2011) Regulatory Domain Selectivity in the Cell-type Specific PKNdependence of Cell Migration. PLoS One. In Press

43 Kitagawa, M., Shibata, H., Toshimori, M., Mukai, H. and Ono, Y. (1996) The role of the unique motifs in the amino-terminal region of PKN on its enzymatic activity. Biochem Biophys Res Commun. 220, 963

44 Yoshinaga, C., Mukai, H., Toshimori, M., Miyamoto, M. and Ono, Y. (1999) Mutational analysis of the regulatory mechanism of PKN: the regulatory region of PKN contains an arachidonic acid-sensitive autoinhibitory domain. J Biochem. 126, 475

45 Ubersax, J. A., Woodbury, E. L., Quang, P. N., Paraz, M., Blethrow, J. D., Shah, K., Shokat, K. M. and Morgan, D. O. (2003) Targets of the cyclin-dependent kinase Cdk1. Nature. 425, 859

46 Davis, R. J. and Czech, M. P. (1984) Tumor-promoting phorbol diesters mediate phosphorylation of the epidermal growth factor receptor. J Biol Chem. 259, 8545 
47 Hunter, T., Ling, N. and Cooper, J. A. (1984) Protein kinase C phosphorylation of the EGF receptor at a threonine residue close to the cytoplasmic face of the plasma membrane. Nature. 311, 480

48 Bao, J., Alroy, I., Waterman, H., Schejter, E. D., Brodie, C., Gruenberg, J. and Yarden, Y. (2000) Threonine phosphorylation diverts internalized epidermal growth factor receptors from a degradative pathway to the recycling endosome. J Biol Chem. 275, 26178

49 Wells, A., Souto, J. C., Solava, J., Kassis, J., Bailey, K. J. and Turner, T. (2002) Luteinizing hormone-releasing hormone agonist limits DU-145 prostate cancer growth by attenuating epidermal growth factor receptor signaling. Clin Cancer Res. 8, 1251

50 Defize, L. H., Boonstra, J., Meisenhelder, J., Kruijer, W., Tertoolen, L. G., Tilly, B. C., Hunter, T., van Bergen en Henegouwen, P. M., Moolenaar, W. H. and de Laat, S. W. (1989) Signal transduction by epidermal growth factor occurs through the subclass of high affinity receptors. J Cell Biol. 109, 2495

51 Linggi, B. and Carpenter, G. (2006) ErbB receptors: new insights on mechanisms and biology. Trends Cell Biol. 16, 649

52 Nishikawa, K., Toker, A., Johannes, F. J., Songyang, Z. and Cantley, L. C. (1997) Determination of the specific substrate sequence motifs of protein kinase $\mathrm{C}$ isozymes. $\mathrm{J}$ Biol Chem. 272, 952 


\section{Table and figure legends}

Table 1

\begin{tabular}{|c|c|c|c|c|}
\hline Family & Subfamily & $\begin{array}{c}\text { PKN1 } \\
\text { Substrate }\end{array}$ & $\begin{array}{l}\text { Database } \\
\text { ID }\end{array}$ & Full name \\
\hline \multirow{15}{*}{$\begin{array}{l}\text { Protein } \\
\text { Kinase }\end{array}$} & \multirow[t]{4}{*}{ TK } & EPH5 & NM_004439.4 & EPH receptor A5 \\
\hline & & PTK2 & $\mathrm{NM}^{-} 153831.2$ & PTK 2 protein tyrosine kinase 2 \\
\hline & & RET & NM_020975.2 & Ret proto-oncogene \\
\hline & & v-erb-b & $\mathrm{NM} 005228$ & Epidermal growth factor rece \\
\hline & TLK & MAP3K9 & NM_033141.2 & Mitogen-activated protein kinase kinase kinase 9 \\
\hline & \multirow[t]{3}{*}{ STE } & OSR 1 & NM_005109 & Oxidative-stress responsive 1 \\
\hline & & STK3 & NM_006281 & Serine/threonine kinase 3 \\
\hline & & STK4 & NM_006282.1 & Serine/threonine kinase 4 \\
\hline & & - & - & \\
\hline & \multirow[t]{2}{*}{ AGC } & GRK4 & NM_182982.2 & G protein-coupled receptor kinase 4 \\
\hline & & $\mathrm{PKC} \zeta$ & NM_002744.2 & Protein kinase $\mathrm{C}$, zeta \\
\hline & \multirow{4}{*}{$\begin{array}{l}\text { CAMK } \\
\text { CMGC }\end{array}$} & MARKL1 & NM_031417.1 & MAP/microtubule affinity-regulating kinase like 1 \\
\hline & & CLK3 & NM_001292 & CDC-like kinase 3 \\
\hline & & PCTAIRE & NM_006201 & PCTAIRE protein kinase 1 \\
\hline & & STK23 & NM_014370.1 & Serine/threonine kinase 23 \\
\hline \multirow[t]{3}{*}{ Enzymes } & Hydrolases & EXO1 & NM_130398.1 & Exonuclease 1 \\
\hline & Transferases & BAZ2B & ВС012576.1 & Bromodomain adjacent to zinc finger domain, 2B \\
\hline & Phosphatases & $\mathrm{CDC} 25 \mathrm{C}$ & NM 001790.2 & Cell division cycle $25 \mathrm{C}$ \\
\hline \multirow{3}{*}{$\begin{array}{l}\text { Protein } \\
\text { binding }\end{array}$} & Cytoskeleton & Adducin 2 & NM 001617 & Adducin 2 (beta) \\
\hline & GTPase & $\begin{array}{l}\text { ARHGAP } \\
15\end{array}$ & NM_018460 & Rho GTPase activating protein 15 \\
\hline & Other & MPP7 & NM 173496 & Membrane protein, palmitoylated 7 \\
\hline Other & & $\begin{array}{l}\text { PPFIBP2 } \\
\text { FAM64A }\end{array}$ & $\begin{array}{l}\text { NM_003621.1 } \\
\text { NM_019013 }\end{array}$ & $\begin{array}{l}\text { PTPRF interacting protein, binding protein } 2 \\
\text { Family with sequence similarity } 64 \text {, member A }\end{array}$ \\
\hline
\end{tabular}

Table 1. Substrates identified for PKN1. The proteins identified as PKN1 substrates in the substrate screen are classified by function. The protein full name and the database ID are also shown.

Figure 1. PKN phosphorylation consensus motif. (A) Representative image of pepchip array (Pepscan) of one of three arrays phosphorylated by PKN1. The open headed arrows show the top 20 phosphorylated peptides. The $25^{\text {th }}$ and $50^{\text {th }}$ phosphorylated peptides are also shown for reference. (B) Phosphorylation consensus motif using WebLog version 3.0 based on the top 20 phosphorylated peptides. The $\mathrm{x}$ axis shows the positions in relation to the Ser/Thr (position 0). The y axis in the upper panel shows the bits. The graphs show the amino acid preference near the Ser/Thr. The height of the letter is proportional of the frequency in the top 20 peptides. The lower graph shows the grouped amino acid probability: $\mathrm{S}$ groups neutral amino acid (Ser, Gly, His, Thr, Ala, Pro); R groups hydrophilic amino acids (Arg, Lys, Glu, Asp, Asn, Gln); I groups hydrophobic amino acids (Ile, Met, Leu, Val, Phe, Trp, Tyr). The red line shows $70 \%$ probability. (C) Phosphorylation of CLIP-170 by PKN1 in an in vitro kinase assay with CLIP-170 as substrate. The first 650 amino acids or the whole CLIP-170 (1393 amino acids) were tested. The samples were incubated for 0-60 min, resolved by SDS-PAGE, stained using Coomassie, and dried. $\gamma\left[{ }^{32} \mathrm{P}\right]$-incorporation was analysed by exposing the gel to a X-film. The data is representative of 3 different experiments. (D) Phosphorylation of CLIP 170 (first 650 amino acids) by PKN1 and PKN3 was carried out as in $1 \mathrm{C}$. The autoradiographs are shown. E, Identification of phosphorylation 
sites in CLIP-170 by PKN1. The tryptic peptide identified by mass spectrometry corresponds to a candidate peptide (residues 310-329) that has an Arg in position -3.

Figure 2. PKN1 protein array. An image of substrate protein array is shown. Comparison of the control slide (no kinase) and the slide incubated in presence of PKN1-GST. The positive controls (proteins that autophosphorylate) are present in the negative control slide and the slide incubated with PKN1; these are important for alignment and normalisation. The $4^{\text {th }}$ and $21^{\text {st }}$ hits are shown in the magnified region.

Figure 3. Phosphorylation of EGFR by PKN1. (A) EGFR sequences present in the susbstrate array; only the second sequence was phosphorylated by PKN1. In the first region of this EGFR substrate, there is a Thr that has an Arg in position -3, Thr-654. X denotes a position with no strict amino acid requirements, $\mathrm{Z}$ a position strictly not tolerating Arg, $\mathrm{Ne}$ a neutral amino acids (Ser, Gly, His, Thr, Ala, Pro), Hi a hydrophilic amino acids (Arg, Lys, Glu, Asp, Asn, Gln) and Ho a hydrophobic amino acids (Ile, Met, Leu, Val, Phe, Trp, Tyr). (B) In vitro kinase assay using the kinase domain of EGFR L861Q as a substrate. The samples were incubated for $15 \mathrm{~min}$, resolved by SDS-PAGE, western blotted and probed with the EGFR Thr-654 antibody and total EGFR antibody as indicated. (C) A431 cells were transfected with $20 \mathrm{nM}$ Luciferase or $20 \mathrm{nM}$ PKNs siRNA. After 96h, the cells were depleted of serum for $5 \mathrm{~h}$ in a $\mathrm{CO}_{2}$ independent medium containing $0.5 \% \mathrm{FBS}$. The cells were treated or not with EGF $100 \mathrm{ng} / \mathrm{ml}$ for $30 \mathrm{~min}$. The cells were collected and probed for EGFR Thr654, total EGFR, PKN1, PKN2, PKN3, and tubulin- $\alpha$ as a loading control. This blot is representative of at least 4 different experiments. (* $p<0.05)$ (D) Quantification of 4 different experiments. (E) A431 cells were treated as in Fig. 3D and with de-convoluted PKNs siRNA. After 96h, the cells were depleted of serum for $5 \mathrm{~h}$ in a $\mathrm{CO}_{2}$ independent medium containing $0.5 \%$ FBS. The cells were treated or not with EGF $100 \mathrm{ng} / \mathrm{ml}$ for $30 \mathrm{~min}$. The cells were collected and probed for EGFR Thr-654, total EGFR, PKN1, PKN2 and tubulin- $\alpha$ as a loading control. (F) Quantification of 2 different experiments. 

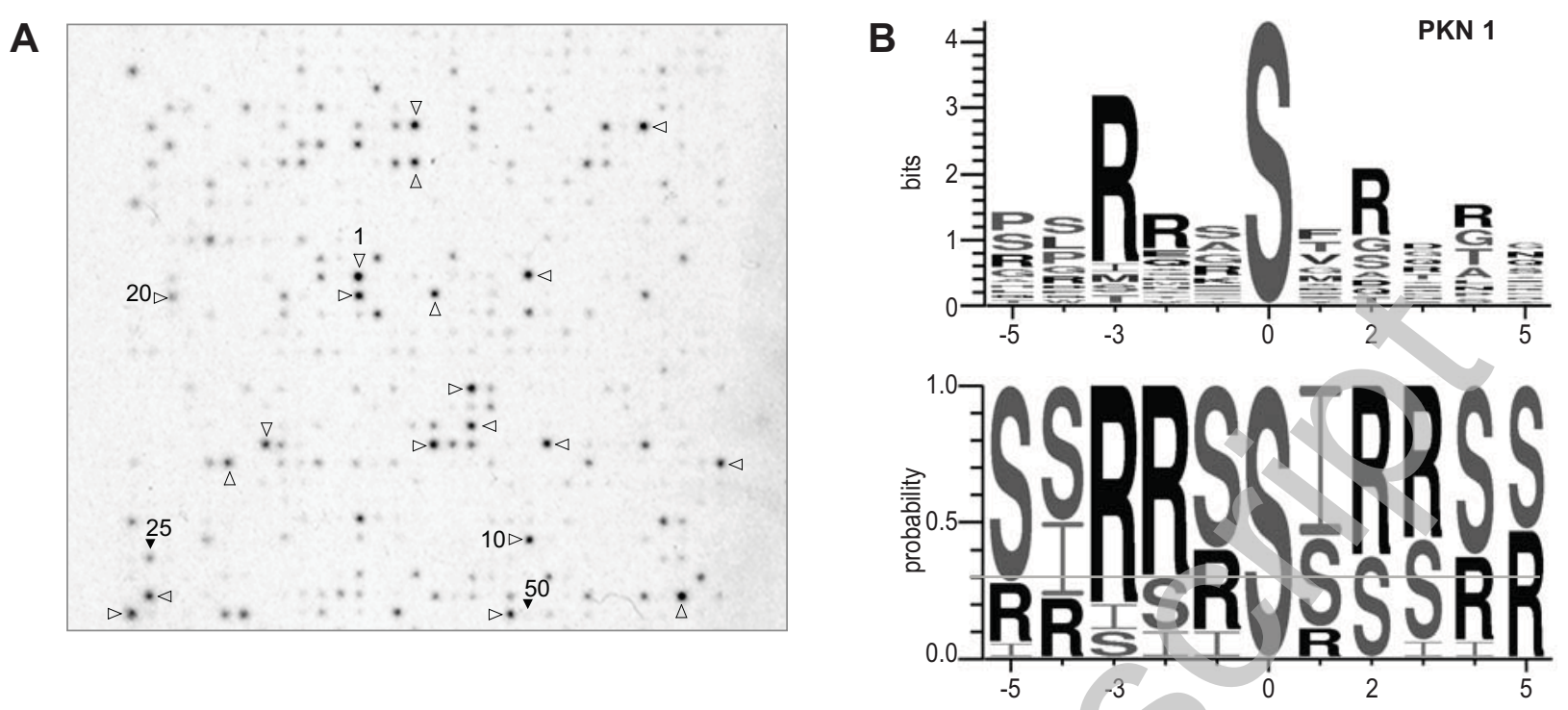

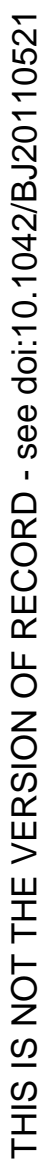

C

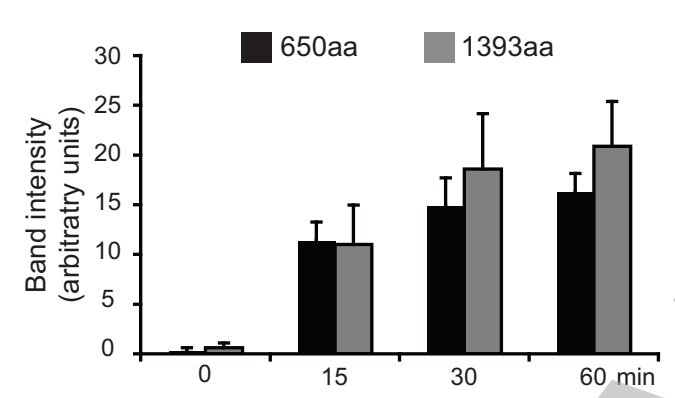

D

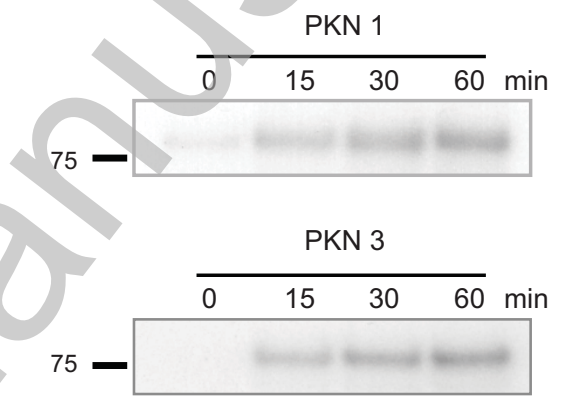

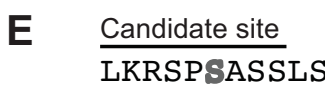

\begin{tabular}{|l|l|l|l|l|l|l|l|l|l|l|}
\hline L & K & $\mathbf{R}$ & S & P & S & A & S & S & L & S \\
\hline
\end{tabular}

Identified site by MS

SPSASSLSSMSSVASSVSSR

\begin{tabular}{lll|l|l|l|l|l|l|l|l|} 
L & K & $\mathbf{R}$ & S & P & $\mathbf{S}$ & A & S & S & L & S \\
\hline
\end{tabular}

Fig 1 


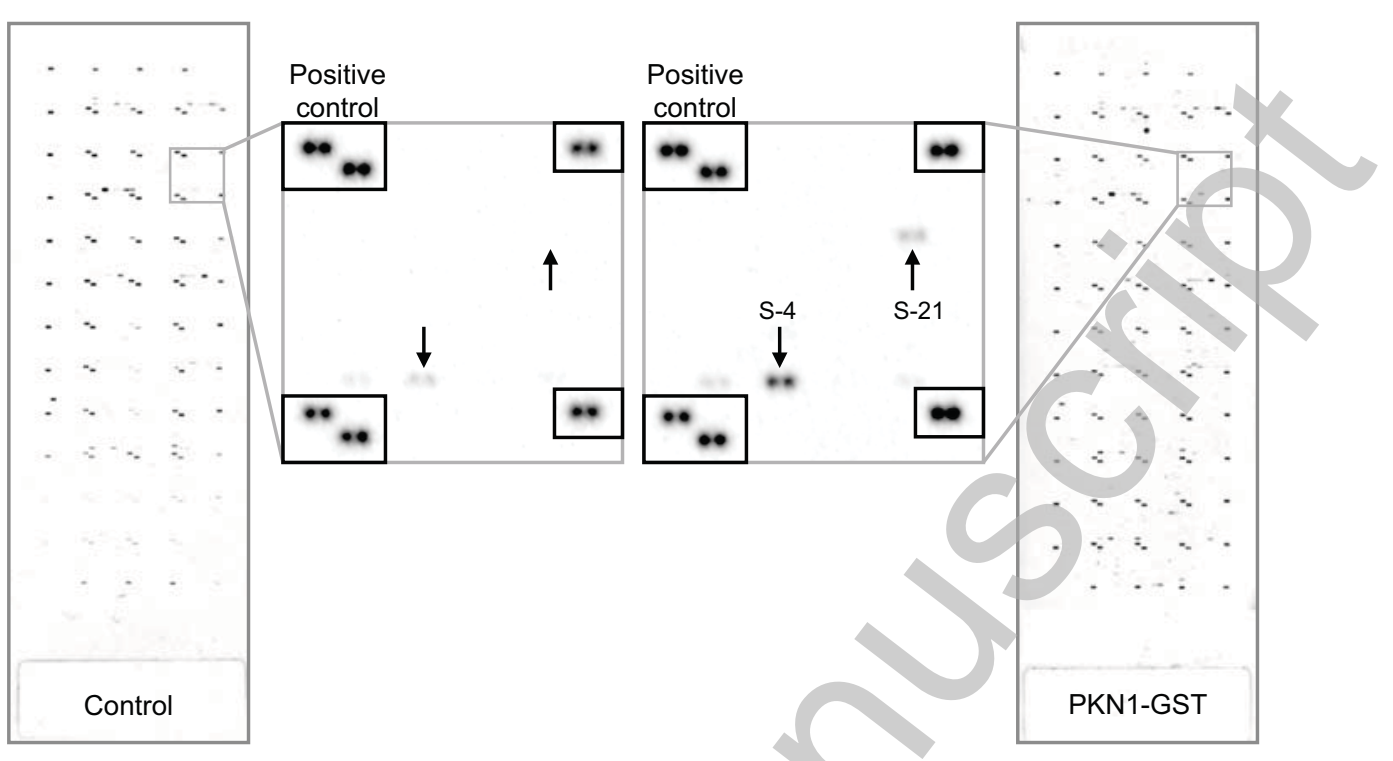

Fig 2 
A

PKN1

substrate

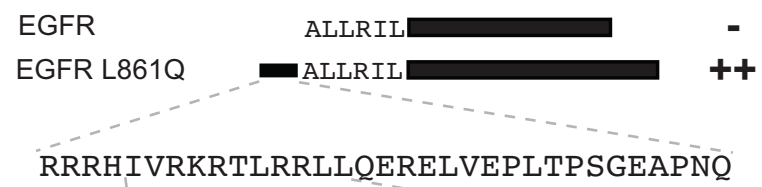

\begin{tabular}{|c|c|c|c|c|c|c|c|c|c|c|}
\hline EGFR & I & V & $\mathbf{R}$ & $\mathbf{K}$ & $\mathrm{R}$ & $\mathbf{T}$ & L & $\mathrm{R}$ & $\mathrm{R}$ & L \\
\hline & $\mathrm{x}$ & $x$ & $\mathbf{R}$ & Hi & $\mathrm{x}$ & $\mathbf{S}$ & $\mathrm{x}$ & $\mathrm{x}$ & $\mathrm{x}$ & $\mathrm{x}$ \\
\hline
\end{tabular}

C

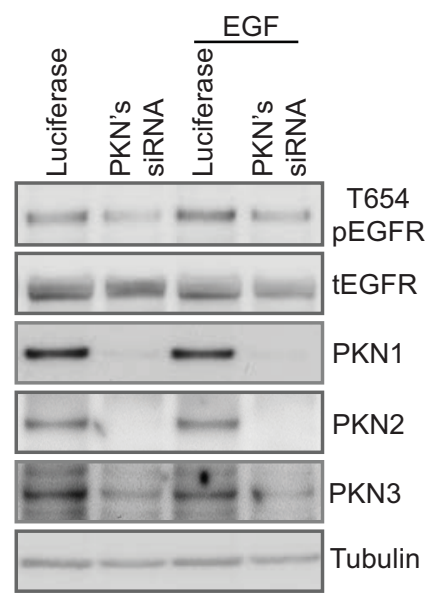

D

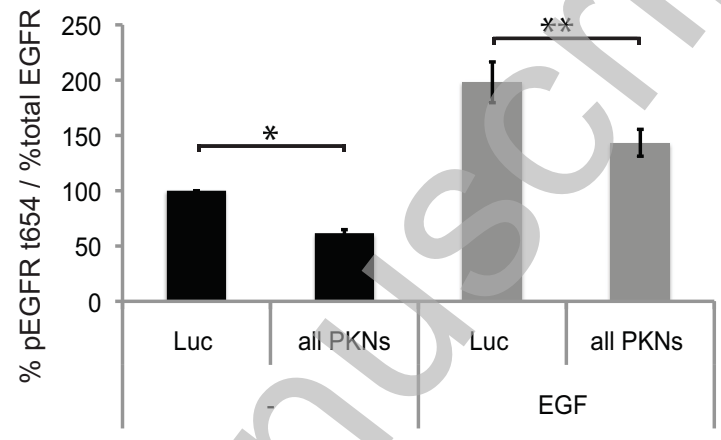

E

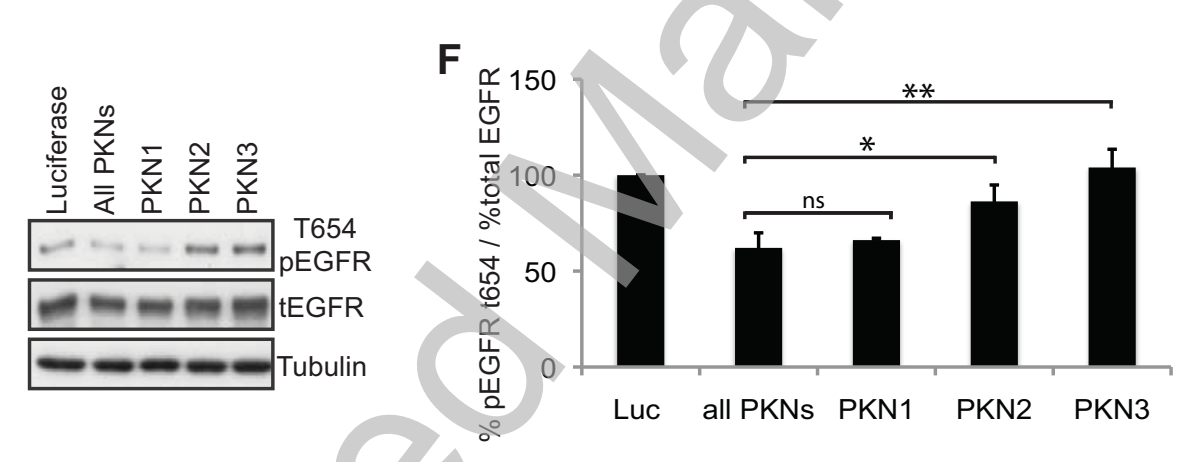

\section{F}

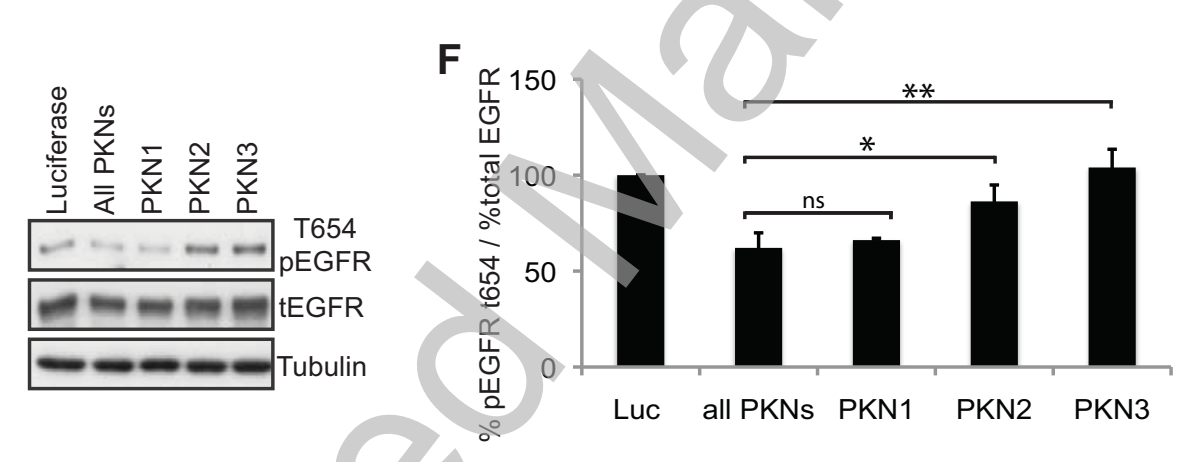

Fig 3

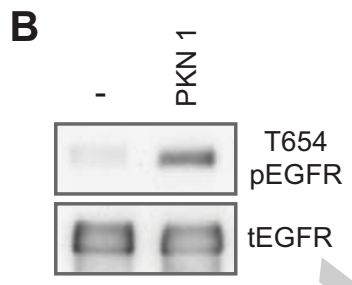

Licenced copy. Copying is not permitted, except with prior permission and as allowed by law. 